\title{
Can fuel cell micro-CHP justify the hydrogen gas grid? Operating experience from a UK domestic retrofit.
}

\author{
P.J. Boait ${ }^{\mathrm{a}^{*}}$, R. Greenough ${ }^{\mathrm{a}}$ \\ ${ }^{a}$ Institute of Energy and Sustainable Development, De Montfort University, Queens Building, \\ The Gateway, Leicester LE1 9BH, UK. Emails: p.boait@dmu.ac.uk,
}

\begin{abstract}
Fuel cell based micro combined heat and power (micro CHP) has been the subject of numerous simulation studies. We report on actual practical performance of a proton exchange membrane fuel cell (PEMFC) micro CHP in a UK dwelling over the 2017-18 heating season and compare its performance with a Stirling engine micro CHP which it replaced. Results show that the PEMFC micro CHP achieves a much higher annual electricity output over a year, with household self-consumption and operating economics dependent on electric vehicle charging. Empirical models derived from this operating experience show that the value of this technology is less sensitive to building parameters, occupancy, and climate change when compared to engine-based micro CHP. We consider the potential role of this technology in the decarbonisation of heat, and highlight the benefit of reliable electricity generation injected into low voltage distribution to mitigate winter demand peaks from heat pumps. A comparative analysis of the primary energy efficiency of different methods of meeting domestic energy demand using natural gas with carbon capture shows that a mixed solution to decarbonisation of heat, combining heat pumps, PEMFC micro CHP, and hydrogen boilers, should not degrade energy efficiency substantially by comparison with an all-electric solution and could be more acceptable to consumers.
\end{abstract}

Keywords: Micro-CHP; PEM fuel cell; electric vehicle charging; primary energy efficiency, hydrogen grid

\footnotetext{
* Corresponding author. Tel.: +44-124-251-1278; fax +44-116-257-7981
} 


\section{Introduction}

Domestic scale micro-combined heat and power (micro-CHP) is a heating system concept that has featured regularly for many years in strategic views of the United Kingdom's road map to mitigation of climate change, and to resolution of the energy trilemma (i.e. making energy supply sustainable, reliable, and affordable). Yet there are relatively few systems actually installed and the benefits that make it of strategic interest are as yet unrealised. The attraction of micro-CHP lies in its potential to improve the exergy efficiency of gas-fuelled domestic heating systems by generating electricity at the same time that heat is produced resulting in lower energy costs for the consumer. Since most heating is required in the winter months when electricity demand is also at its highest there is a critical correlation in the demand for heat and electricity which micro-CHP can satisfy. Its electricity output is potentially also complementary in its seasonality to that generated by solar photovoltaics (PV) which have reached a high level of penetration ( 1 in 30 of the $25 \mathrm{M}$ homes in the UK) $[1]$.

In 2005 this journal published a paper [2] evaluating a Stirling engine based micro-CHP which exemplified the kind of system that UK energy policy of the time, as expressed in [3], envisaged would be rolled out to 400,000 homes by 2010 . In practice the total number of installations known to the UK Feed-in Tariff Register [1] in 2017 was 707. The reasons for the failure of this technology to be adopted at scale are complex but two factors are evident. Firstly, manufacturers have found it difficult to produce heat engine based products for this market at a profitable combination of cost, sales volume, and reliability. At least three domestic micro-CHP products have been promoted to the UK home heating market, delivered in small numbers, then withdrawn from sale ${ }^{1}$. Secondly, the financial benefit to the

\footnotetext{
${ }^{1}$ These are the Whispergen, Baxi Ecogen, and Flow Genlec. They may still be available for niche heating and electricity supply applications, such as yachts in the case of the Whispergen.
} 
consumer depends on the amount of electricity generated which in turn depends on heat demand. As [2] showed, the concept of micro-CHP is inherently less attractive for smaller and well insulated homes. The overriding policy drive to reduce heat demand in homes through improved insulation has diminished the population of homes where a heat engine micro-CHP of the form evaluated in [2] is potentially viable.

Meanwhile the UK policy and technology landscape has evolved since 2005 . The dramatic fall in the cost of wind and PV generation has justified a strategy for electricity generation in which these sources, supported by nuclear baseload generation, electricity storage, and "smart" demand response measures to match fluctuating supply with demand [4], can deliver a substantially decarbonised electricity system by 2050 . However, the future demand placed on this electricity system is strongly dependent on the outcome from a presently unresolved issue, the pathway (or combination of pathways) to decarbonisation of heat for buildings. The current dominance of natural gas fuelled heating and investment in the national gas network has led to a degree of lock-in, and uncertainty concerning the policy measures and technical solutions needed to overcome this [5], [6], [7]. Four broad approaches have been identified:

1. Reduction of heat demand through improved insulation. This is a "low regret" option that must be pursued in any pathway.

2. Electrification of heat through deployment of heat pumps. A policy measure to promote heat pumps, the Renewable Heat Incentive [8], has been in place since 2014 but uptake is slower than hoped [9], [10] and the feasibility of a mass transition from gas boilers to heat pumps is unproven.

3. District heat networks, supplied with heat from MW scale CHP plant fuelled by biomass or natural gas with carbon capture. The high installation cost of heat networks makes this option more attractive for dense urban areas; the viability 
of deployment in the medium and low density suburbs common in the UK that are currently supplied by gas is unproven.

4. Conversion of the gas network to carry hydrogen generated by reforming natural gas in large plants with carbon capture and storage (CCS). The national scale conversion of gas appliances to run on a different gas has a precedent in the conversion from town gas (containing a high proportion of hydrogen) to natural gas that took place successfully in 1967-77.

The UK Government's advisory body on climate change strategy recommended in [11] that the hydrogen grid option be retained and its feasibility further investigated. This recommendation was taken forward into the 2017 Clean Growth Strategy [12]. To prove the feasibility of converting the gas grid to hydrogen plans have been developed for a large scale trial covering the city of Leeds [13]. The key advantage of this option for the consumer is that conversion of a gas boiler to hydrogen is a much less disruptive process than replacement with a heat pump which in a retrofit usually requires new and larger heat emitters and an intrusive external fan unit or ground loop. The challenges presented by the need to generate and distribute an additional $40 \mathrm{GW}$ of electricity required to meet winter demand with an all electric strategy [6] will also be mitigated if some of the heat load continues to be met with gas.

In this paper we report on the practical performance and strategic potential of a type of heating appliance with potential value for the hydrogen option, a fuel cell based micro-CHP. The device on which data has been collected is installed in the same dwelling as used for [2], allowing an accurate assessment of the performance improvement over heat engine based micro-CHP. This fuel cell employs proton exchange membrane (PEM) technology which is designed to operate with hydrogen as the input gas. For the appliance under test the hydrogen is derived from natural gas by an integrated steam methane reforming process. 
Section 2 further elaborates the policy background, the underlying thermodynamic efficiencies and carbon emission savings to be gained from micro-CHP, and describes the PEM technology as implemented in the trial appliance. Section 3 reports on the actual performance of the appliance in terms of both energy conversion efficiency and cost, and derives a simple model allowing its performance in other dwellings to be predicted. Section 4 uses this model in combination with a model of the UK climate under climate change to assess the future benefits of this technology under different climate and household scenarios. This analysis supports a discussion in Section 5 of the potential impact of this form of microCHP in the context of the hydrogen grid decarbonisation pathway, with final conclusions in Section 6.

\section{Background}

\subsection{Carbon capture methods and the hydrogen grid}

The case for conversion of the UK's natural gas grid to carry hydrogen depends strongly on the need for continued use of fossil fuels combined with carbon capture and storage (CCS). There is broad agreement that without CCS it will be very difficult to meet the committed goal of $80 \%$ reduction in greenhouse gases by $2050[11,14,15]$, as other methods of low carbon heating gas production (hydrogen from electrolysis of water and biogas) cannot deliver the required capacity. There are three well understood methods of performing carbon capture on fossil fuels in the kind of large scale plant needed to minimise the energy and investment costs.

1. Pre combustion. The fuel is gasified (coal) or reformed (natural gas) to create hydrogen and carbon monoxide (syngas). The carbon monoxide then reacts with water in a "water shift" process to create more hydrogen, and the $\mathrm{CO}_{2}$ is separated for storage. 
2. Post combustion. The fuel is combusted with air to create heat and the $\mathrm{CO}_{2}$ scrubbed from the flue gases using any of a range of methods.

3. Oxyfuel combustion with recycling of $\mathrm{CO}_{2}$. The most promising form of this approach is the Allam Cycle [17]. Natural gas is combusted with pure oxygen extracted from air, heating $\mathrm{CO}_{2}$ as the working fluid which directly drives a compact turbine to generate electricity. $\mathrm{CO}_{2}$ can be extracted as an almost pure stream at a pressure suitable for capture.

At the present time none of these methods is self-evidently the dominant technology. All have been implemented among the relatively few MW-scale plants that exist globally. The pre combustion process, the only one to produce hydrogen, is well proven as a method for industrial scale production of hydrogen, but hydrogen is not ideal as a combustible gas to drive a gas turbine directly [18] leading to a relatively low efficiency when used to generate electricity in a conventional plant. Post combustion CCS has the difficulty that the $\mathrm{CO}_{2}$ is only at a concentration of about $7 \%$ making the capture process expensive [16], but it is a practical addition to combined cycle gas turbine (CCGT) electricity generation increasing electricity cost by about 33\% [19]. The Allam Cycle is claimed to be capable of 59\% efficiency with CCS [17], which would be comparable to conventional CCGTs without CCS, but the first MW scale plant has only just started operation so the technology is immature.

This uncertainty concerning CCS reinforces the uncertainty concerning decarbonisation of heat. Post combustion or oxyfuel are clearly matched to a solution where heat pumps are preferred, whereas pre-combustion and hydrogen gas distribution make sense within a strategy that includes retention of a large population of gas consuming domestic appliances that convert to hydrogen. Resolution of a strategy optimising investment in these options demands a comprehensive assessment of the relative efficiency and cost of each, quantified end-to-end from primary energy to delivery of heat in homes. Hydrogen will 
unavoidably be a more expensive fuel than natural methane, so efficiency of its use will be critical to its acceptability. The fuel cell micro CHP is recognised by hydrogen grid studies as a key technology in this regard - in [20] Dodds and Demoulin predict that by 2050 fuel cell micro CHP could provide about $1 / 3$ of residential heat demand.

\subsection{Emission and efficiency benefits of micro $\mathrm{CHP}$}

Simulation studies by Peacock and Newborough [21],[22], and others contemporaneous with [2] and [3] investigated the system sizing and performance criteria of domestic micro $\mathrm{CHP}$ and the reduction in carbon emissions that could be achieved. With the then prevailing carbon intensity of grid electricity at $0.43 \mathrm{~kg} / \mathrm{kWh}$ a reduction of about $0.5 \mathrm{t}$ in $\mathrm{CO}_{2}$ emissions per annum relative to a condensing gas boiler was expected [21] from a $1 \mathrm{kWe}$ Stirling engine system similar to that described in [2], representing an emissions saving of 9-16\% depending on the dwelling. A critical limitation of engine-based systems identified in these studies is the fixed ratio of heat and electricity outputs, usually in the range $5: 1$ to $8: 1$, combined with a fixed generator power. This means that variation in heat output to match seasonal and weather-dependent heat demand can only be achieved by varying the duty cycle of the appliance, so the electrical energy generated is correspondingly reduced as heat demand falls. Also, the frequent stop-start cycles under intermittent operation in spring and autumn present a challenge to product durability, contributing to the observed low uptake of the technology.

These studies, and subsequent economic studies such as [23, 24], considered the performance of fuel cell based systems based on the evidence available at the time from early prototypes. They identified a key advantage over heat engine systems that the ratio of heat to electricity output could be about 1:1, allowing the variation in heat demand to be satisfied by an auxiliary gas boiler. This allows much longer running time for the fuel cell ensuring higher overall electricity production and potentially better reliability and economics. The potential 
reduction in carbon emissions identified in [21] also increases to $0.9 \mathrm{t}$ per annum for a $1 \mathrm{kWe}$ fuel cell unit.

Given the reduction in the aggregate carbon intensity of UK electricity to about $0.25 \mathrm{~kg}$ $\mathrm{CO}_{2} / \mathrm{kWh}$ in 2017 [25] and expected fall to below $0.1 \mathrm{~kg} \mathrm{CO} / \mathrm{kWh}$ by 2030 , the direct reduction in carbon emissions from displacing grid electricity with gas fuelled micro CHP generation is a diminishing benefit, although useful in the near term until all coal-fired generating plants close by 2025 [26], and of marginal benefit as long as CCGT generation is displaced. If a fuel cell micro $\mathrm{CHP}$ is connected to a hydrogen grid, its operational $\mathrm{CO}_{2}$ emissions are zero, and the more interesting question is the overall primary energy efficiency in the context of providing low carbon heat. The Leeds study [13] expects an energy efficiency of $68 \%$ in converting natural gas to hydrogen in an industrial-scale steam methane reformation plant. If the hydrogen is converted into electricity and useful heat by a fuel cell micro CHP with an overall efficiency of $80 \%$ then the net efficiency before distribution losses is $56 \%$. This compares with $47 \%$ for CCGT production of electricity with post combustion $\mathrm{CO}_{2}$ capture [19] and 59\% for the Allam cycle [17]. However, heat pumps with an EU-compliant Coefficient of Performance $(\mathrm{CoP})$ of 2.5 will convert even the CCGT output to heat with a first law efficiency of $47 \% * 2.5=117 \%$ before distribution losses. Fuel cell micro CHP can thus be seen as a technology that is complementary to heat pumps, by providing electricity with high primary energy efficiency, while satisfying a valuable proportion of heat demand. In [27], using the method originally employed by MacKay [28] to argue that micro CHP is not a good option, Staffell shows that, because of the expected improvement in performance over engine-based CHP, fuel cell micro CHP technologies are potentially more efficient in producing heat and electricity than the alternative combination of CCGT and heat pump preferred in [28], for the specific ratios of heat to electricity production they offer. A solution to the decarbonisation of heat using both heat pumps and fuel cell CHP 
technologies should therefore optimise primary energy efficiency as long as real life performance is within the target parameters framed by these simulation studies. This premise is considered further in Section 4 based on the real life fuel cell CHP performance revealed by the present study.

\subsection{The EneFarm PEM fuel cell and trial installation}

Recognising the potential of domestic fuel cell micro CHP, the Japanese government has sponsored a programme of research, development, and deployment, entitled "EneFarm", leading to a current position where about 30,000 units were installed annually in 2016 [29]. Of these, about half are PEM fuel cell devices, developed by Panasonic, of the type evaluated in the present study. This maturity has led to its integration with a condensing boiler, by German manufacturer Veissmann, to create a product offered to the European domestic heating market [30] that was suitable for the trial dwelling. The present study reports on the performance of this hybrid appliance. Figure 1 provides a schematic diagram of the main components and energy flows, while Figure 2 shows the internal layout of the actual system as installed in the garage of the dwelling, with the main components highlighted. A detailed description of the design decisions, processes and subsystem functions within this type of PEM FCCHP is provided by Gandiglio et. al. in [31].

The main thermal characteristics of the dwelling are summarised in Table 1, determined as annual mean values from the energy inputs, internal temperatures, and external temperatures measured during this study using a comprehensive instrumentation suite capturing all relevant energy flows and temperatures at 5 minute intervals or less. The heat emitters employed for space heating comprise both panel radiators and underfloor heating in the proportions indicated in the table. They are able to provide comfortable winter heating with flow and return temperatures of $50^{\circ} \mathrm{C}$ and $40^{\circ} \mathrm{C}$ respectively, ensuring efficient extraction of heat from the fuel cell stack operating at about $65^{\circ} \mathrm{C}$ and condensing operation 
of the auxiliary boiler. Domestic hot water is not supplied by the water heating capability of the FCCHP in this installation, because of the difficulty of integrating it efficiently with an existing solar thermal hot water system with immersion heater top-up. The annual household consumption of electricity in 2017 was $3930 \mathrm{kWh}$, more than the applicable UK median of $3100 \mathrm{kWh}$ but below the upper quartile level of $4600 \mathrm{kWh}$ [32]. The residents also have an electric vehicle (EV), a BMW i3 which in 2017 drew an additional annual $2247 \mathrm{kWh}$ from the home electricity system in covering $14907 \mathrm{~km}^{2}$, allowing this study to evaluate the additional self-consumption achieved when supplying an electric vehicle. This pattern of consumption continued throughout the present study.

Table 1. Building thermal characteristics

\begin{tabular}{|l|l|}
\hline Parameter & Value \\
\hline Overall thermal loss rate (measured) & $350 \mathrm{~W} / \mathrm{K}$ \\
\hline Aggregate thermal inertia & $15 \mathrm{kWh} / \mathrm{K}$ \\
\hline Heated floor area (40\% underfloor, $60 \%$ panel radiators) & $155 \mathrm{~m}^{2}$ \\
\hline
\end{tabular}

\footnotetext{
${ }^{2}$ This distance also required $420 \mathrm{kWh}$ from public charging points.
} 


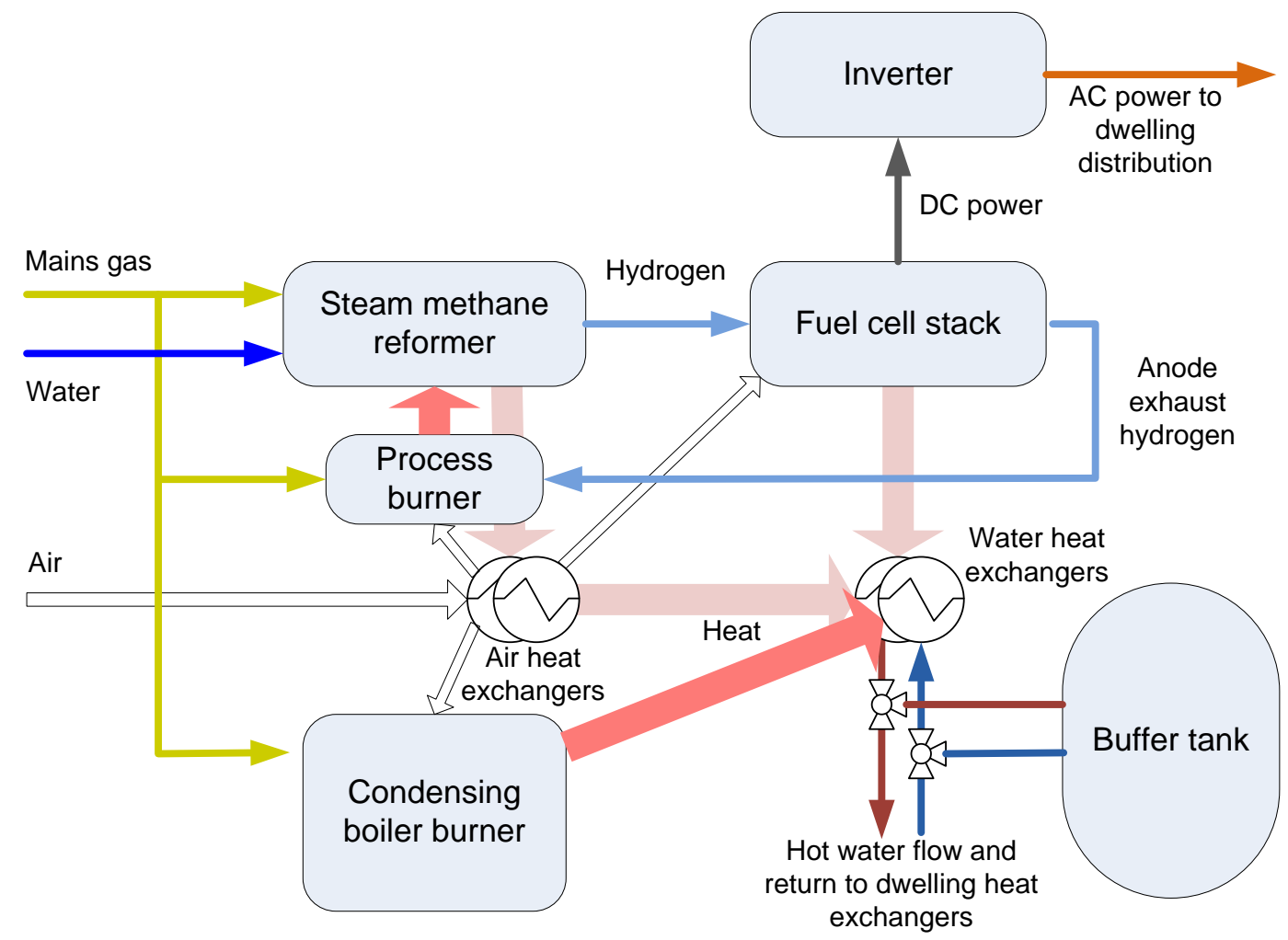

Fig.1 Simplified schematic of PEM fuel cell CHP unit

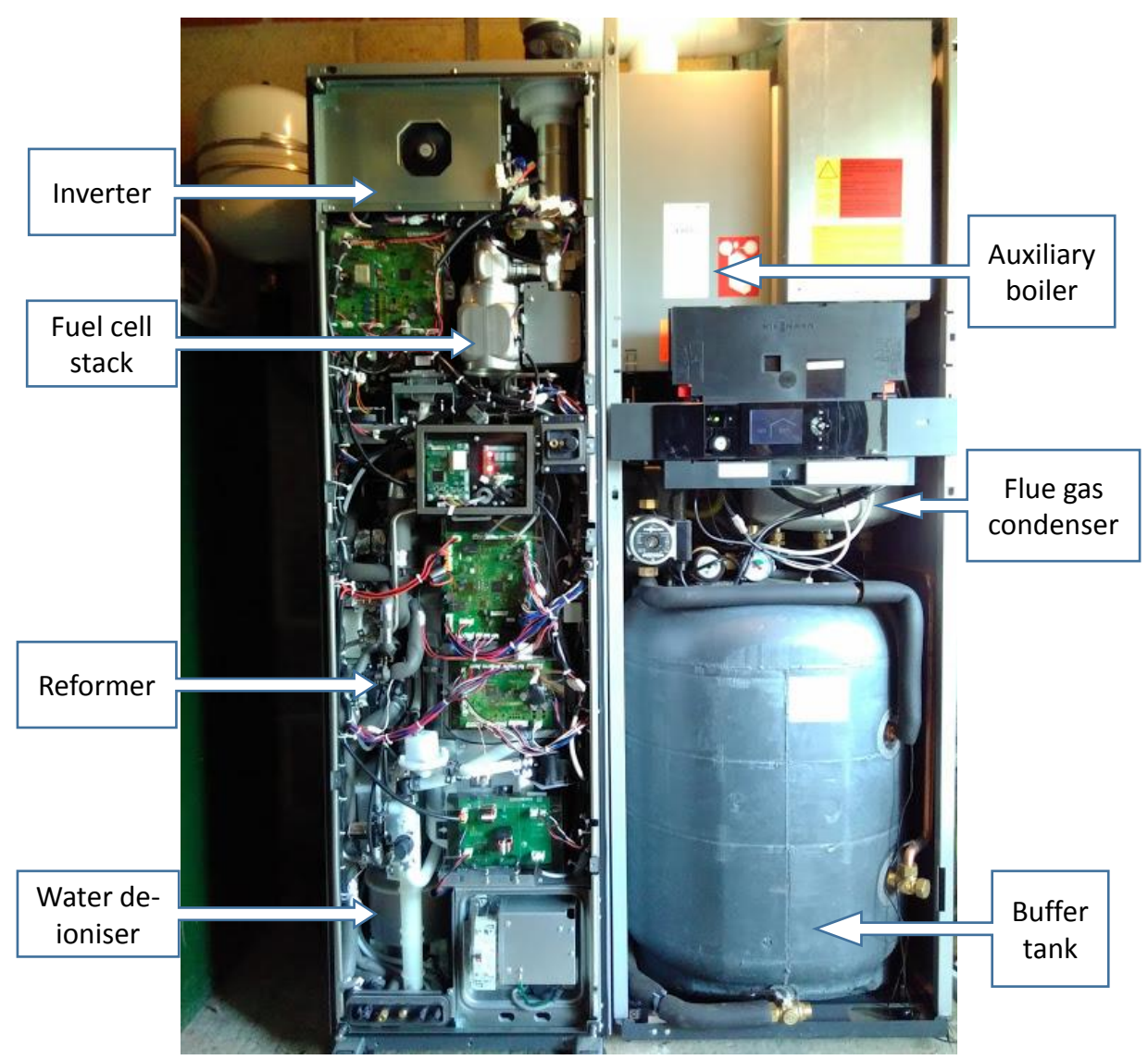

Fig.2 PEM fuel cell CHP unit as installed 


\section{Performance of the PEM fuel cell CHP unit}

\subsection{Heat and electricity outputs}

The control system for the fuel cell subsystem operates on an approximately 24-hour cycle. For about 21 hours of the day, as long as the fuel cell heat output of $0.95 \mathrm{~kW}$ can be consumed, it continues to generate an AC output of $0.73-0.75 \mathrm{~kW}$ from the inverter. These outputs are fixed and can only be modulated via the on/off duty cycle. Then for the remaining 3 hours, it executes a re-initialisation cycle which resets the interlocking control loops described in [31] so that all operating parameters are maintained within safe bands for long term reliability. The CHP system consumes about $0.01 \mathrm{~kW}$ of AC power internally so $0.72-$ $0.74 \mathrm{~kW}$ is delivered to the household electricity distribution. A typical daily profile as seen at the generation meter is shown in Figure 3. Negative values indicate power drawn from the household distribution during the re-initialisation phase. The three hour re-initialisation window advances or delays by 5-15 minutes each day thereby preventing the aggregation of large power transients across a population of these devices.

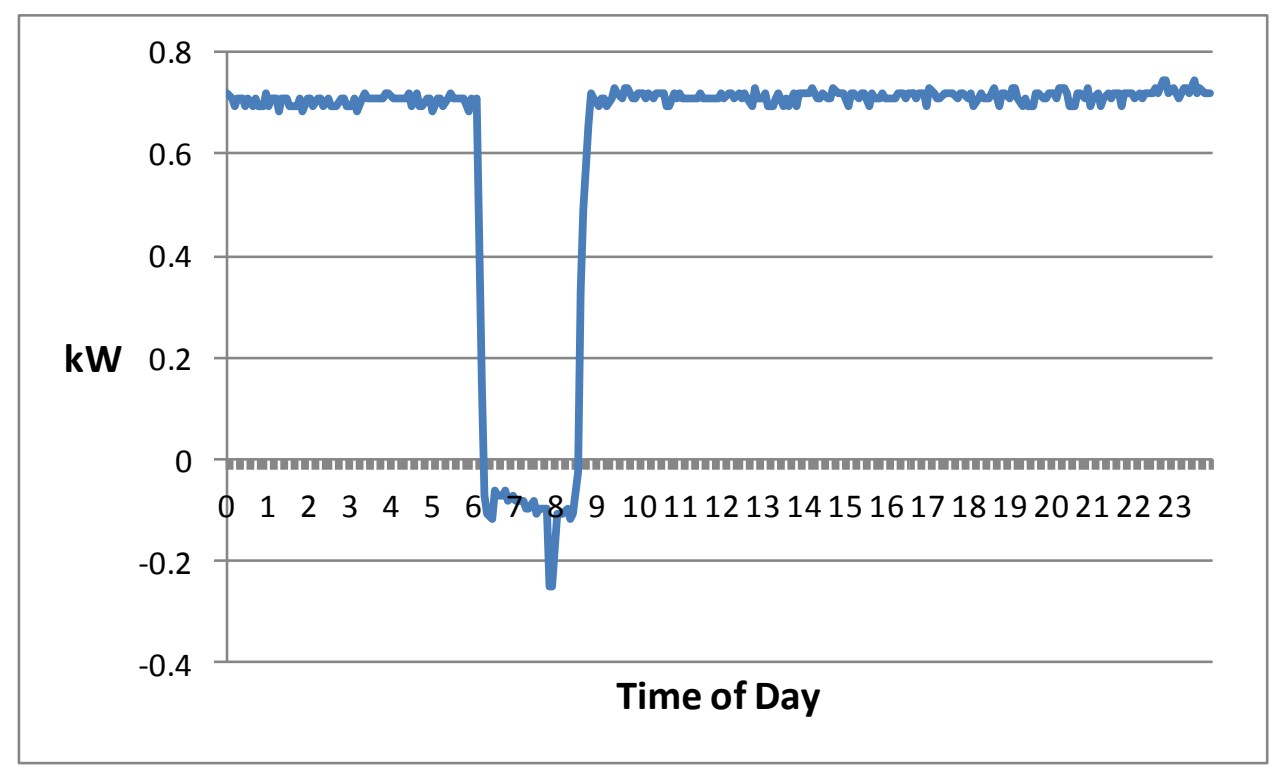

Fig.3 Typical daily profile of electricity generation 
The heat output from the whole system including the condensing boiler varies according to demand up to $19 \mathrm{~kW}$, although in the winter under test, heat demand did not exceed $8 \mathrm{~kW}$. The buffer tank is used to smooth heat demand from the dwelling so that the ability to consume the heat output from the fuel cell is maintained. If the heat load falls below $20 \mathrm{kWh} /$ day the fuel cell re-initialisation interval is extended proportionately to reduce the heat output to match demand, with a corresponding reduction in electricity generation over the day. In Figure 4 daily electricity generation is plotted against whole system heat output for the entire period of 153 days under test (20 Dec 17- 21 May 18). The scatter of points above $20 \mathrm{kWh}$ heat output per day, but below the dominant line of electricity generation at about $15.3 \mathrm{kWh} /$ day arises from days when either the re-initialisation phase was extended for some internal reason, or heat emitters were less efficient than usual causing the return temperature to be too high for the fuel cell to operate, or the mains electrical power supply was interrupted causing shutdown and a relatively slow recovery. After 21 May 18 the system was put into a standby mode with no heat output as the dwelling did not require space heating, but electricity generation operated intermittently when the buffer tank cooled down sufficiently due to standing thermal losses (measured as $5.5 \mathrm{kWh} /$ day) to allow fuel cell operation. This mode yielded the data point at $2 \mathrm{kWh}$ daily electricity output, with zero useful heat demand delivered to heat emitters, visible in Figure 4. 


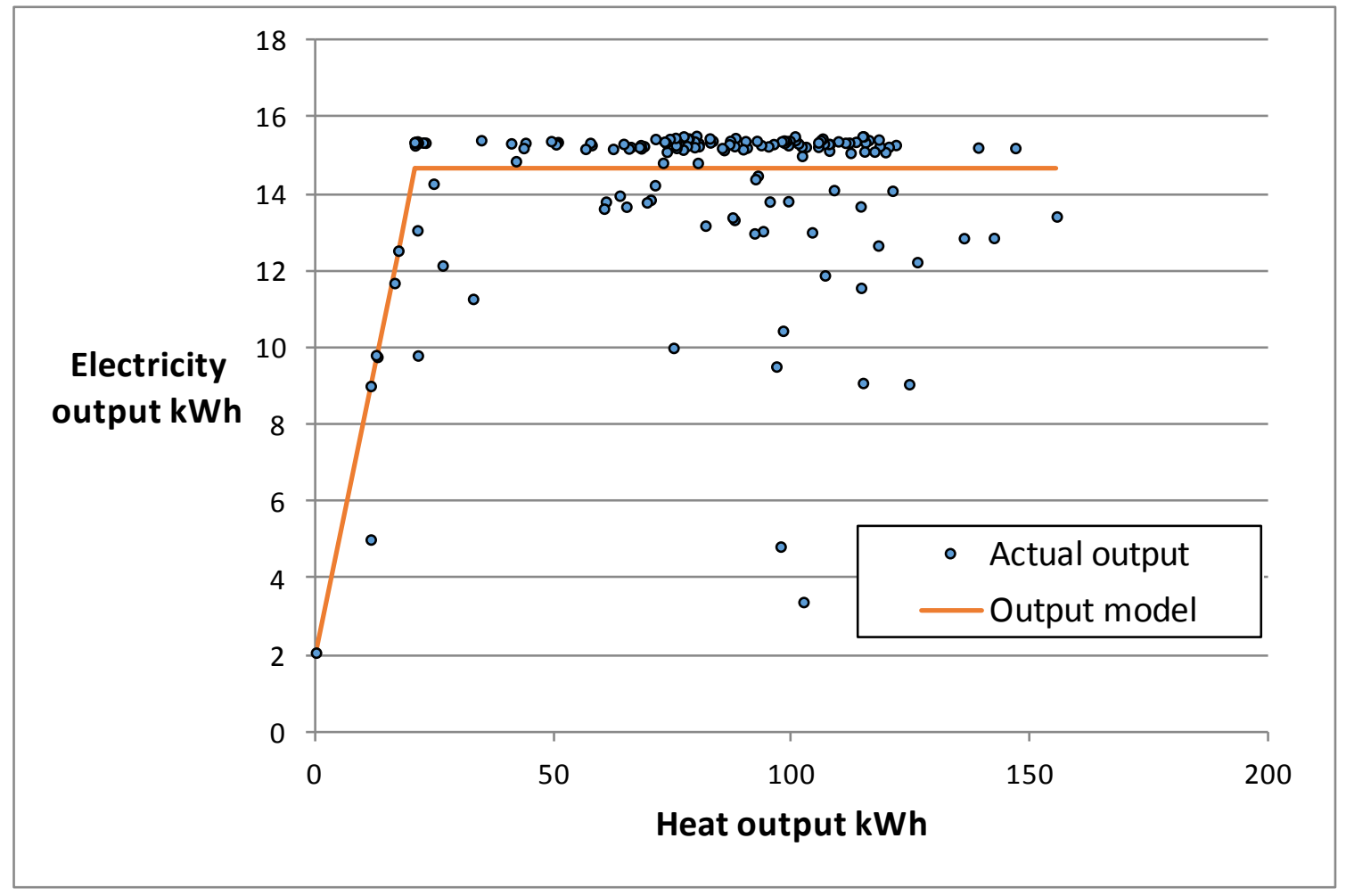

Fig. 4. Scatter plot of daily electricity and useful heat production Dec 2017-May 2018

The aggregate outputs over the test period, overall efficiency, and proportions of electricity generation consumed locally, are shown in Table 2 below. These data are extrapolated to give the expected totals for a whole year in the table using the model described in the next section. Efficiency for each day was calculated simply as the sum of electricity and heat outputs measured over 24 hours divided by the $\mathrm{kWh}$ value of the gas consumed using the supplier's published $\mathrm{HHV}^{3}$ calorific value per $\mathrm{m}^{3}$ of the gas $(39.3$ $\mathrm{MJ} / \mathrm{m}^{3}$ ). To evaluate the extrapolation, the assumption for weather over the rest of 2018 was that the degree-days of heating load for each day would be equal to the average for that calendar day for the last six years $(2012-2017)$ at the location ${ }^{4}$ of the test system. The small reduction in efficiency over the year is due to the consumption required to maintain standby mode over the summer months, while the lower self consumption figures arise because higher

\footnotetext{
${ }^{3}$ Higher Heating Value - the calorific value of the gas including the latent heat of combustion products.

${ }^{4}$ Cheltenham, UK, weather station IGLOUCES6 used for degree-day data.
} 
self consumption during the winter months is now averaged over the whole year. For comparison, actual outputs achieved by the Stirling engine micro CHP system in the same house for 2005 (when data for [2] was collected) are given. The higher heat output for that year reflects the poorer insulation of the house at that time.

Table 2. Energy outputs, efficiency, and self-consumption for system under test

\begin{tabular}{|l|l|l|l|l|l|}
\hline Interval & $\begin{array}{l}\text { Electricity } \\
\mathrm{kWh}\end{array}$ & $\begin{array}{l}\text { Heat } \\
\mathrm{kWh}\end{array}$ & Efficiency & $\begin{array}{l}\text { Self- } \\
\text { consumption } \\
\text { (inc. EV) }\end{array}$ & $\begin{array}{l}\text { Self- } \\
\text { consumption } \\
\text { (ex. EV) }\end{array}$ \\
\hline $\begin{array}{l}\text { Test period 20 Dec 17 } \\
\text { 21 May 18 }\end{array}$ & 2195 & 12312 & $81.6 \%$ & $50 \%$ & $41 \%$ \\
\hline Projection for year & 3903 & 18613 & $80.8 \%$ & $49 \%$ & $38 \%$ \\
\hline $\begin{array}{l}\text { Stirling engine mCHP } \\
\text { unit for year 2005 }\end{array}$ & 2680 & 25765 & $80.1 \%$ & Not available & $56 \%$ \\
\hline
\end{tabular}

\subsection{Output model}

Based on the results above, a simple model relating electricity output to daily heat demand was derived as shown in Figure 4. For heat demand $Q>=20 \mathrm{kWh} /$ day, electricity generated $E=14.6 \mathrm{kWh} /$ day. This figure for generation is the arithmetic mean of the data points with qualifying heat output, excluding the two low generation outliers at a heat output of about 100kWh which arose when installation defects were corrected. It therefore reflects the occasional reductions in generation that will occur in normal operation. For $Q<$ $20 \mathrm{kWh} /$ day, linear regression of the data points available (excluding the outlier arising from a temporary heat emitter issue at $11 \mathrm{kWh}$ heat, $5 \mathrm{kWh}$ electricity), yields the function:

$$
E=0.6 Q+2.1
$$


with an $R^{2}$ value of 0.99 . This equation allows an empirical model of first law efficiency $\eta$ dependency on useful heat load $Q$ to be derived. Assuming losses comprise a fixed standing element $s$ and output - dependent element $k(E+Q)$, then:

$$
\eta=(E+Q) /(E+Q+k(E+Q)+s)
$$

From measurement $k=0.175$ and $s=5.5$. Then substituting for $E$ using (1) and simplifying gives:

$$
\eta=(1.6 Q+2.1) /(1.9 Q+8.0)
$$

Figure 5 below shows this model as the continuous line, plotted with actual measured values of daily efficiency during April-May 2018. A factor affecting the efficiency of the trial system is that it was installed outside the thermal envelope of the dwelling, in a garage. Had it been installed within the thermal envelope most of the static losses (about $4 \mathrm{kWh}$ per day) would contribute to the heating demand. Figure 5 therefore also shows the efficiency that would have been achieved for space heating demand if those losses were able to be considered useful output.

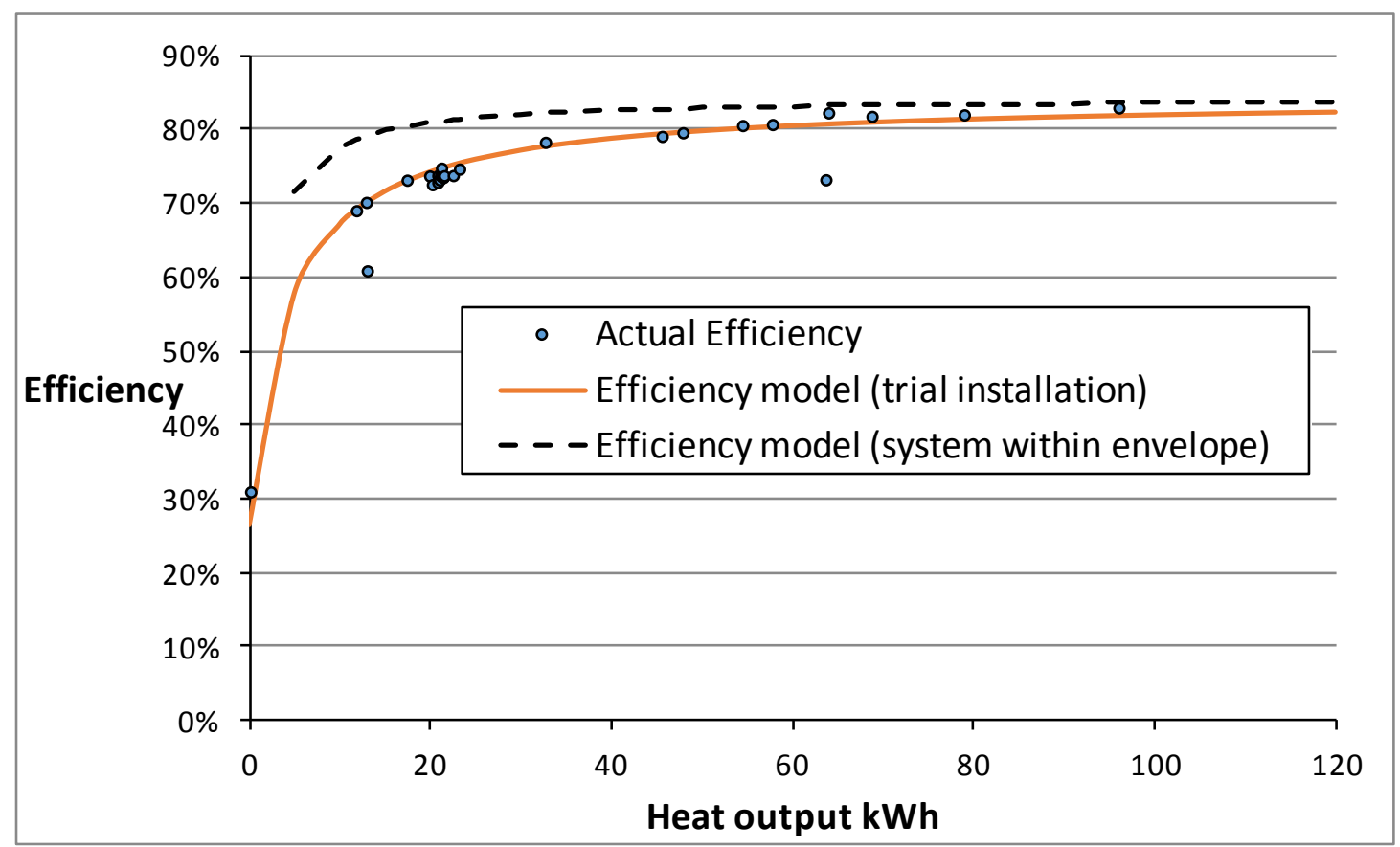

Fig. 5 System efficiency as a function of heat demand 


\subsection{Current cost effectiveness and comparison with mechanical micro CHP}

It is evident that despite the lower electrical output power of the fuel cell micro CHP compared to the Stirling engine micro CHP evaluated in [2], the overall proportion of selfconsumption, excluding the impact of EV charging, is substantially lower (41\% rather than $56 \%$ ). This partly arises from the longer running times which mean that more generation occurs overnight when electricity demand is lower. It is also a function of the improvements in efficiency of lighting, entertainment and refrigeration appliances which present a continuous load that can be satisfied by micro CHP. In the case of the trial dwelling, the average January evening demand has fallen from $850 \mathrm{~W}$ to $440 \mathrm{~W}$ between 2005 (when data for [2] was collected) and 2018 with no change in occupancy. This combination of overnight running and appliance efficiency improvements implies that the variations in use of these appliances that depend on occupancy will have much less effect on self-consumption than previously expected (a self-consumption range of $40 \%$ to $63 \%$ depending on occupancy was predicted in [2]). The main sensitivity to occupancy will be via hot water use, where the resulting heat demand can sustain efficient operation of the fuel cell over the summer months. This sensitivity is further investigated in the next section.

As Table 2 indicates, electric car charging improves self consumption substantially. Charging consumption over the trial period averaged $6.1 \mathrm{kWh} /$ day, arising from an average distance driven of $34 \mathrm{~km} /$ day with efficiency of $18 \mathrm{kWh} / 100 \mathrm{~km}$. This vehicle usage is close to the UK average for a household car of 21.6 miles/day $(34.8 \mathrm{~km})$ as found by the 2014 National Travel Survey [33]. All charging was performed at the lowest standard rate (6A, $1.4 \mathrm{~kW})$ which did not at any time constrain EV use.

Table 3. Financial costs and benefits over a year for the trial system 


\begin{tabular}{|l|l|l|}
\hline Benefit or cost & Rate per kWh & Value \\
\hline Feed-in generation tariff for 3903 kWh [34] & $£ 0.1395$ & $£ 544$ \\
\hline Export tariff (deemed at 50\% of generation) [34] & $£ 0.053$ & $£ 103$ \\
\hline Avoided import including EV charging & $£ 0.1733^{*}$ & $£ 331$ \\
\hline Gas consumed in generation at 81\% efficiency & $£ 0.0409^{*}$ & $£-197$ \\
\hline Net benefit for year & & $£ 782$ \\
\hline
\end{tabular}

- Actual tariffs charged to the household by their gas and electricity supplier Ecotricity Ltd, which were competitive UK market rates for 2018

The installed cost of the present system was $£ 11,000$ representing an additional cost of about $£ 8000$ for the fuel cell compared to simply installing a conventional condensing gas boiler. The net benefit from the fuel cell shown in Table 3 therefore corresponds to a simple payback time of 10 years, which conveniently corresponds to the 10 year duration of the feed-in tariff commitment provided to each installation by the UK feed-in tariff scheme for micro CHP [34]. However, the UK feed-in tariff regime ceases at the end of March 2019 so new installations after that date would not be economic at the above cost. A careful analysis of the cost reduction trajectory for EneFarm systems since the inception of the project was performed by Staffell and Green in [35]. They conclude that a cost of $\$ 3500$ ( $£ 2700$ at current exchange rates) is an achievable target in the $2020-2030$ period. The realism of this cost is reinforced if grid-supplied hydrogen is available allowing the fuel reforming subsystem to be eliminated. At this target cost it is possible to conceive a viable business case for the technology without the need for a feed-in tariff subsidy. Some sensitivities of the business case are explored in the next section.

\section{Climate and household scenarios}

The amount of electricity produced by a fuel cell system of this type depends on the heating load presented by the dwelling, which in turn depends on the climate and the heat loss rate through the dwelling fabric, and also the potential for an adequate heat load during 
the summer months allowing all-year operation. It is likely that by 2030 and beyond there will be perceptible changes to the UK climate, and further improvements to insulation will have been made to many buildings. It is therefore useful to test the sensitivity of the results given in Table 3 to four factors:

1. Subsidy-free operation following closure of the feed-in tariff regime.

2. Consumption of domestic hot water.

3. Dwelling thermal loss rate.

4. Predictions for the UK climate in 2030 and 2050.

The UK Government's proposal to replace feed-in tariffs [36] is a market-based regime in which domestic generators would be paid for their actual electricity exports (measured by smart metering) depending on their value to the system as a whole. Since fuel cell systems can export during the winter at peak demand times they are likely to attract a higher average export rate than the existing deemed tariff rate shown in Table 3. For the purposes of this sensitivity test an export rate of $£ 0.07 / \mathrm{kWh}$ is assumed. For avoided import (i.e. selfconsumption), and the cost of gas for electricity generation, the Table 3 figures of $£ 0.1733$ and $£ 0.0409$ respectively are used,

In respect of the second factor, if it allows year-round operation at acceptable efficiency it mitigates sensitivity to the last two, so it is an important consideration. An empirical model of UK domestic hot water consumption was obtained by the Energy Saving Trust [37]. This expresses the daily average volume $V$ litres consumed in terms of the household occupancy $N$ in the equation:

$$
V=46+26 N
$$

Because the PEM fuel cell in the present system operates at $60^{\circ} \mathrm{C}$ it supplies domestic hot water at $50^{\circ} \mathrm{C}$. To ensure Legionella disinfection the control subsystem schedules an occasional episode of heating at $60^{\circ} \mathrm{C}$ using the condensing boiler. A typical temperature for 
cold water mains supply in the UK in July is $18^{\circ} \mathrm{C}$ [37]. So the heat energy $Q \mathrm{kWh}$ required from the fuel cell to deliver $V$ litres of hot water is:

$$
Q=4.18 V(50-18) / 3600=0.037 V \mathrm{kWh}
$$

The factor 4.18 is the specific heat of water in $\mathrm{J} / \mathrm{gK}$. For a 2-person household, from (4) and (5) hot water demand would present a heat load of $3.6 \mathrm{kWh} /$ day, allowing (from (1) and (3)) production of $4.3 \mathrm{kWh} /$ day of electricity when space heating is not required, with an overall efficiency of $53 \%$. The impact of hot water use and replacement of feed-in tariffs with a market-based export tariff rate on annual generation, efficiency, and financial benefit, in households with 1,2,3 and 4 occupants is shown in Table 4 . All other assumptions (dwelling, weather,, self-consumption) are unchanged from Table 3. The electricity generation and resulting financial benefit are significantly improved by all-year running, without a material loss in overall efficiency. The financial benefit may be sufficient to incentivise adoption if the system cost reduction discussed in 3.3 is achieved.

Table 4. Sensitivity of annual generation and benefits to domestic hot water use

\begin{tabular}{|l|l|l|l|l|}
\hline Occupancy & 1 & 2 & 3 & 4 \\
\hline Electricity generation over year kWh & 4301 & 4371 & 4438 & 4503 \\
\hline Useful heat output over year kWh & 16180 & 16531 & 16882 & 17233 \\
\hline Net financial benefit & $£ 292$ & $£ 296$ & $£ 301$ & $£ 305$ \\
\hline Efficiency over year & $78.6 \%$ & $78.7 \%$ & $78.9 \%$ & $79.0 \%$ \\
\hline
\end{tabular}

If the analysis in Table 4 is repeated for a dwelling with a much lower specific thermal loss rate of $120 \mathrm{~W} / \mathrm{K}^{5}$, but all other assumptions remain unchanged, the modelling results are as shown in Table 5. This is the outcome that might be expected in a recently-constructed, well insulated small family house [38]. In all occupancy cases the annual generation is higher than that modelled in [2] for engine-based micro CHP, which even in a large, poorly

\footnotetext{
${ }^{5}$ About $20 \mathrm{~W} / \mathrm{K}$ of this loss rate will be supplied by appliance and lighting electricity consumption of about $12 \mathrm{kWh} /$ day so the demand on the heating system would be about $100 \mathrm{~W} / \mathrm{K}$
} 
insulated, and high occupancy home with a specific thermal loss rate of $450 \mathrm{~W} / \mathrm{K}$, could only achieve $3265 \mathrm{kWh}$. However, there is some impairment of annual efficiency due to the low level of space heating, and the financial benefit of the fuel cell is significantly reduced.

Table 5. Sensitivity of annual generation and benefits to domestic hot water use in a dwelling with specific thermal loss rate of $120 \mathrm{~W} / \mathrm{K}$.

\begin{tabular}{|l|l|l|l|l|}
\hline Occupancy & 1 & 2 & 3 & 4 \\
\hline Electricity generation over year kWh & 3506 & 3652 & 3793 & 3926 \\
\hline Useful heat output over year kWh & 5317 & 5668 & 6020 & 6371 \\
\hline Net financial benefit & $£ 202$ & $£ 209$ & $£ 215$ & $£ 221$ \\
\hline Efficiency over year & $70.9 \%$ & $71.6 \%$ & $72.1 \%$ & $72.7 \%$ \\
\hline
\end{tabular}

To test the resilience of this technology under climate change, performance has been evaluated using synthetic Test Reference Year (TRY) climate data produced under the PROMETHEUS project by Eames et.al. [39]. These data are based on the UKCP09 climate projections [40]. For this purpose TRYs for Bristol ${ }^{6}$ have been used, based on medium emissions scenario A1B, and $50^{\text {th }}$ percentile (median) estimates of the outcome in 2030 and 2050 constructed using the methodology devised by Levermore and Parkinson [41]. These TRYs present a significantly lower space heating demand, 1675 and 1527 degree days for 2030 and 2050 respectively $^{7}$ compared to 1874 degree days for the 2018 data and model used for the results in Tables 2-5. Results for dwelling losses of $350 \mathrm{~W} / \mathrm{K}$ (as used for Tables 2-4) and $100 \mathrm{~W} / \mathrm{K}$ are shown in Table 6, occupancy of 2 is assumed in all scenarios.

\footnotetext{
${ }^{6}$ The nearest city to the trial system location.

${ }^{7}$ Degree days determined using a base temperature of $15.5^{\circ} \mathrm{C}$
} 
Table 6. Sensitivity of annual generation and efficiency to climate change

\begin{tabular}{|l|l|l|l|l|}
\hline Climate scenario & $\begin{array}{l}2030, \text { loss } \\
\text { rate 350 } \\
\mathrm{W} / \mathrm{K}\end{array}$ & $\begin{array}{l}\text { 2030, loss } \\
\text { rate 120 } \\
\mathrm{W} / \mathrm{K}\end{array}$ & $\begin{array}{l}\text { 2050, loss } \\
\text { rate 350 } \\
\mathrm{W} / \mathrm{K}\end{array}$ & $\begin{array}{l}\text { 2050, loss } \\
\text { rate 120 } \\
\mathrm{W} / \mathrm{K}\end{array}$ \\
\hline $\begin{array}{l}\text { Electricity generation over year } \\
\mathrm{kWh}\end{array}$ & 4062 & 3445 & 3971 & 3363 \\
\hline Useful heat output over year kWh & 14811 & 5177 & 13732 & 4869 \\
\hline Efficiency over year & $78.1 \%$ & $70.7 \%$ & $77.7 \%$ & $70.1 \%$ \\
\hline
\end{tabular}

\section{Discussion}

The real-life performance and sensitivity analysis presented in the previous sections shows that, by comparison with the heat engine micro-CHP evaluated in [2], the present appliance is far more capable of maintaining a useful heat-led electricity output over a range of dwelling types, occupancy, and climate scenarios. The large number of units deployed in Japan indicates that operational reliability is good, while Ellamla et. al. report in [42] a durability for this PEMFC technology of 60,000 hours for generator power $>80 \%$ of specification. If the cost reductions projected in [35] can be achieved, and micro CHP has a policy-supported role in the strategy for decarbonisation of heat, the large scale adoption envisaged in [3] could be realised. It will be an attractive technology for suburban homes where EV charging from the domestic supply is possible, or a domestic battery is installed allowing electricity demand peaks to be met from stored micro CHP generation. A reduction in size of the plant will also be helpful in allowing it to be installed within the building envelope as is normal for conventional gas boilers, providing a useful efficiency gain. As noted earlier, a policy-supported role is most likely to arise if conversion of the natural gas grid to hydrogen goes ahead. 
To assess the benefit of this technology to the hydrogen grid, the efficiency models derived in section 3 allow a comparison of the primary energy efficiency of three options for supplying domestic electricity and heat using natural gas with carbon capture:

1. CCGT with post combustion carbon capture and heat pumps

2. CCGT with post combustion carbon capture and hydrogen boilers

3. PEM fuel cell micro CHP supplied with hydrogen from methane reforming with carbon capture.

The assumptions employed in this comparison are summarised in Table 7 , and the results plotted in Figure 6 for different ratios of heat to electricity within domestic energy demand. This presentation is intended to illustrate how the advantage of the heat pump option identified in [28] depends on this ratio. The advantage reduces or disappears at the low ratios which will become more dominant as climate change and EV adoption take effect. The range of heat pump Seasonal Performance Factors ${ }^{8}$ shown (2-3) is based on actual measured UK values reported by Low et al. [43]. A key assumption in addition to those in the table is that a PEM fuel cell CHP supplied from a hydrogen grid would give the same performance as the present appliance. In practice the elimination of methane reforming should improve the appliance efficiency. Given the expected levels of annual heat demand shown in Table 6, Figure 6 indicates that a mixed decarbonisation solution, including both heat pumps and a hydrogen grid supplying conventional boilers and fuel cell CHP, would not degrade overall primary energy efficiency substantially by comparison with an all-electric solution. This finding is likely to apply to non-domestic heating, but derivation of efficiency/demand ratio curves for non-domestic heat pump and CHP systems equivalent to those in Figure 6 is a "future work" task dependent on publication of suitable performance data.

\footnotetext{
${ }^{8}$ SPF H4 values i.e. coefficient of performance measured over a heating season including ancillaries such as circulation pumps.
} 
Table 7. Assumptions for primary energy efficiency comparison

\begin{tabular}{|l|c|}
\hline Parameter & Value \\
\hline $\begin{array}{l}\text { Electricity generation efficiency of CCGT with post } \\
\text { combustion carbon capture (LHV value) [19] }\end{array}$ & $47 \%$ \\
\hline Conversion factor LHV to HHV [25] & 1.109 \\
\hline $\begin{array}{l}\text { Energy efficiency of hydrogen production by large scale } \\
\text { steam methane reforming [13] }\end{array}$ & $68 \%$ \\
\hline Losses in electricity transmission and distribution [44] & $7.4 \%$ \\
\hline $\begin{array}{l}\text { Range of domestic heat pump Seasonal Performance } \\
\text { Factors [40] }\end{array}$ & $6000 \mathrm{kWh}$ \\
\hline $\begin{array}{l}\text { Average annual household electricity use including EV } \\
\text { charging }\end{array}$ & $90 \%$ \\
\hline Efficiency of hydrogen-fuelled condensing boiler & $2-3$ \\
\hline
\end{tabular}

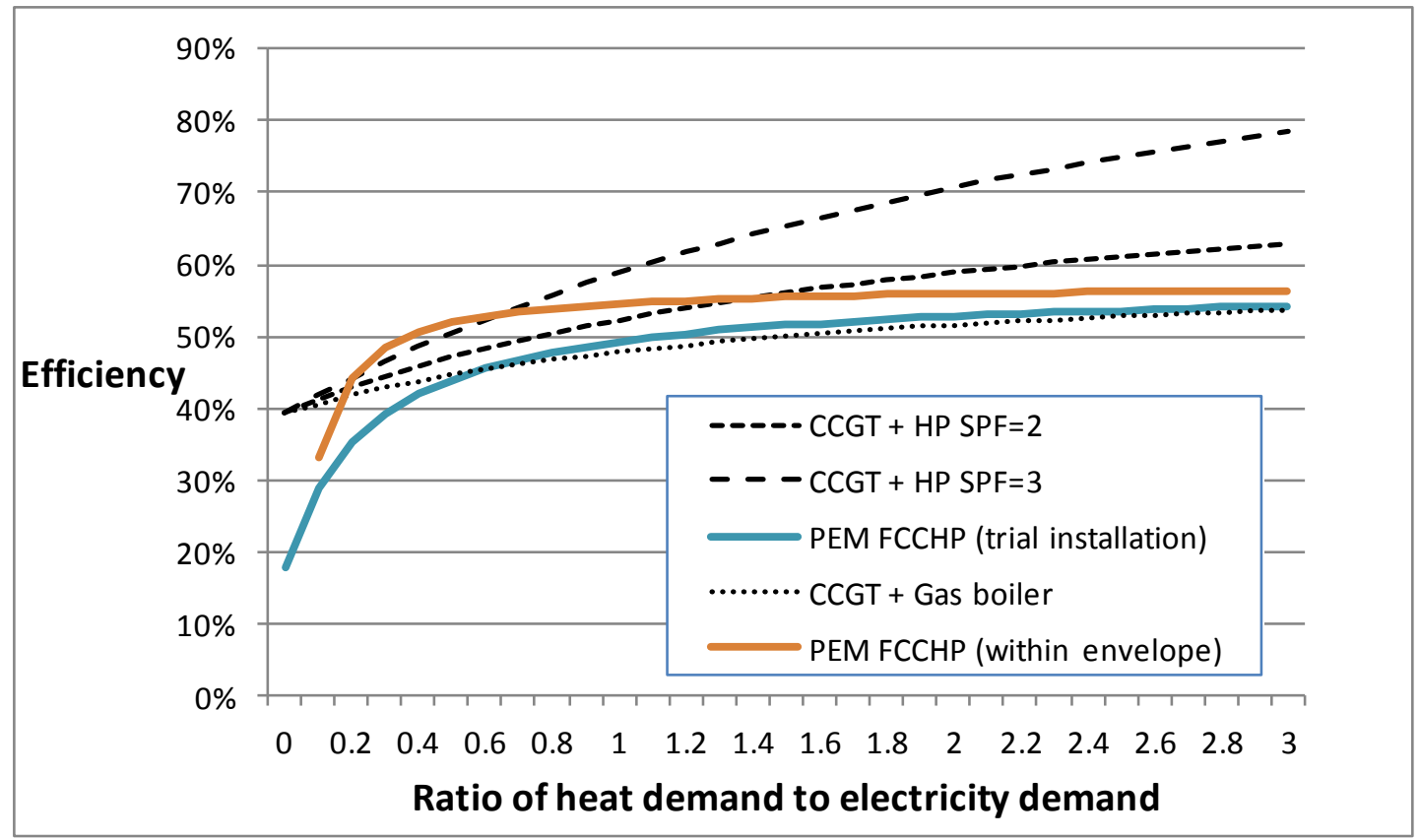

Figure 6. Efficiency comparison of options for decarbonised domestic energy

The critical contribution that hydrogen-powered fuel cell micro CHP could make to this mixed approach would be to provide a constant level of zero carbon electricity generation throughout the heating season with limited dependency on weather, as the capacity would 
only reduce during an unnaturally warm spell. This steady and reliable output would serve as baseload generation similar to that provided by nuclear power, with the advantage that being delivered directly into the low voltage network it could help to satisfy increasing demand from heat pumps and EVs without the need for network reinforcement. If $1 / 3$ of the $18 \mathrm{M}$ homes in England currently heated by natural gas converted to this form of micro CHP it would provide firm winter capacity of $3.7 \mathrm{GW}$ - i.e. rather more than the $3.2 \mathrm{GW}$ provided by the controversial Hinkley Point nuclear reactors currently under construction. Taking a different perspective, if the 150 homes on a typical suburban LV network and the gas grid were decarbonised with heat pumps in 50 homes, hydrogen fuel cell micro CHP in 50 homes, and the rest simply converted from natural gas boilers to hydrogen, then $80 \%$ of the peak winter demand of the heat pumps would be met by the micro CHP. Assumptions in this example are a specific thermal loss rate of $120 \mathrm{~W} / \mathrm{K}$ for the heat pump homes and a CoP of 3 for the heat pumps. This kind of mixed deployment could mitigate the strategic risks identified in [6] while retaining the high primary energy efficiency of heat pumps for homes with a suitable combination of good insulation and heat emitter sizing. The merits of this mixed approach have been recognised in other studies such as Dodds et. al [45]. The policy support required for fuel cell micro CHP to achieve this kind of outcome would be realistic payment for export electricity from dwellings with the technology, recognising the value of a reliable reduction of peak LV demand at the transformer.

A balanced mix of heating technologies across the homes on an LV network, of the kind proposed in the above example, is of course unlikely to occur where individual consumers make their own decisions on the choice of heating appliance. But it might be possible under a service-oriented business model for the delivery of domestic energy as proposed by the UK's Energy Catapult and other authors [46,47]. With this concept, consumers would pay a simple tariff for a specified and committed level of comfort in terms 
of room temperature and availability of domestic hot water. The technology used to provide this comfort level would then be the responsibility of the energy supplier, who would be obliged to co-ordinate with the gas and electricity distribution network operators to ensure a satisfactory mix on local grids.

\section{Conclusions}

The operational performance of the PEM fuel cell micro CHP evaluated in this study has shown that this technology offers a substantial improvement over heat engine based micro CHP, in respect of the ability to deliver useful and sustained electricity generation over a range of dwelling, occupancy, and climate scenarios. The measured performance broadly matches results predicted by simulation studies allowing the potential benefits they have identified to be realised. Its adoption in the UK on the large scale previously envisaged depends on the cost reduction achieved as manufacturing volumes increase, and the extent to which the existing (but short-lived) policy support in the form of a feed-in tariff is replaced by a regime that reflects the role of the technology in decarbonisation of heat. The most promising role arises if the conversion of the gas grid to hydrogen takes place. This will reduce the appliance cost by eliminating the methane reforming subsystem, and allow clustered installations on LV distribution to mitigate winter peaks in demand from local heat pumps and EV charging.

\section{Acknowledgements}

The authors would like to thank the European Commission for partial funding under the Horizon 2020 PACE project of the PEM fuel cell micro CHP evaluated in this study. 


\section{References}

[1] Department for Business, Energy \& Industrial Strategy. Monthly feed-in tariff commissioned installations (2018). https://www.gov.uk/government/statistics/monthly-small$\underline{\text { scale-renewable-deployment }}$

[2] P. Boait, R. Rylatt, M. Stokes. Optimisation of consumer benefits from micro Combined Heat and Power, Energy and Buildings 38 (2005) 981-987

[3] Department for Environment, Food, and Rural Affairs. The Government's Strategy for Combined Heat and Power to 2010 (2004).

https://aleo.org.uk/downloads/root/regions/uk/documents/chp_strategy.pdf

[4] National Infrastructure Commission, Smart Power (2016).

https://www.gov.uk/government/uploads/system/uploads/attachment_data/file/505218/IC_En ergy_Report_web.pdf

[5] P.E. Dodds, W. McDowall. The future of the UK gas network, Energy Policy 60 (2013) 305-316

[6] N. Eyre, P. Baruah. Uncertainties in future energy demand in UK residential heating, Energy Policy 87 (2015) 641-653

[7] M. Chaudry, M. Abeysekera, S. H. R. Hosseini, N. Jenkins. Uncertainties in decarbonising heat in the UK, Energy Policy 87 (2015) 623-640

[8] Ofgem. Domestic Renewable Heat Incentive (2018), https://www.ofgem.gov.uk/environmental-programmes/domestic-rhi

[9] J.R. Snape, P. J. Boait, R.M. Rylatt. Will domestic consumers take up the renewable heat incentive? An analysis of the barriers to heat pump adoption using agent-based modelling, Energy Policy 85 (2015) 32-38.

[10] Department for Business, Energy \& Industrial Strategy. RHI deployment data: December (2017), https://www.gov.uk/government/statistics/rhi-deployment-data-december$\underline{2017}$ 
[11] Committee on Climate Change. Next steps for UK heat policy (2016).

https://www.theccc.org.uk/publication/next-steps-for-uk-heat-policy/

[12] Department for Business, Energy \& Industrial Strategy. The Clean Growth Strategy leading the way to a low carbon future (2017),

https://www.gov.uk/government/publications/clean-growth-strategy

[13] Leeds City Gate Team, H21 Report (2016) https://www.northerngasnetworks.co.uk/wpcontent/uploads/2017/04/H21-Report-Interactive-PDF-July-2016.compressed.pdf

[14] Committee on Climate Change. An independent assessment of the UK's Clean Growth Strategy (2018). https://www.theccc.org.uk/wp-content/uploads/2018/01/CCC-IndependentAssessment-of-UKs-Clean-Growth-Strategy-2018.pdf

[15] C. McGlade, S. Pye, P. Ekins, M. Bradshaw, J. Watson. The future role of natural gas in the UK: A bridge to nowhere? Energy Policy 113 (2018) 454-465

[16] D.Y.C. Leung, G. Caramanna, M.M. Maroto-Valer. An overview of current status of carbon capture and storage technologies, Renewable and Sustainable Energy Reviews 39 (2014) 426-443

[17] R. Allam, S. Martin, B. Forrest, J. Fetvedt, X. Lu, D. Freed, G.W. Brown, T. Sasaki, M. Itoh, J. Manning. Demonstration of the Allam Cycle: An update on the development status of a high efficiency supercritical carbon dioxide power process employing full carbon capture, Energy Procedia 114 (2017) 5948-5966

[18] J. Gibbins, H. Chalmers. Carbon capture and storage, Energy Policy 36 (2008) 43174322.

[19] International Energy Agency. CO2 Capture as a Factor in Power Station Investment Decisions (2006) http://www.ieaghg.org/docs/overviews/2006-8.pdf

[20] P.E. Dodds, S. Demoullin. Conversion of the UK gas system to transport hydrogen, Hydrogen Energy 38 (2013) 7189-7200.

[21] A.D. Peacock, M. Newborough. Impact of micro-CHP systems on domestic sector CO2 emissions, Applied Thermal Engineering 25 (2005) 2653-2676 
[22] A.D. Peacock, M. Newborough. Impact of micro-combined heat-and-power systems on energy flows in the UK electricity supply industry, Energy 31 (2006) 1804-1818

[23] A. Hawkes, I. Staffell, D. Brett, N. Brandon. Fuel cells for micro-combined heat and power generation. Royal Society of Chemistry Energy and Environmental Science (2009), 2, 729-744.

[24] H. Ren, W. Gao, Y. Ruan. Optimal sizing for residential CHP system . Applied Thermal Engineering (2008), 28, 514-523.

[25] Department for Business, Energy \& Industrial Strategy. Updated energy and emissions projections (2018). https://www.gov.uk/government/publications/updated-energy-andemissions-projections-2017

[26] Department for Business, Energy \& Industrial Strategy. Coal generation in Great Britain: The pathway to a low-carbon future (2018)

https://www.gov.uk/government/consultations/coal-generation-in-great-britain-the-pathwayto-a-low-carbon-future

[27] I. Staffell. Zero carbon infinite COP heat from fuel cell CHP, Applied Energy 147 (2015) 373-385

[28] D. J. C. MacKay, Sustainable Energy: Without the Hot Air, ISBN 9780954452933. UIT Cambridge (2009).

[29] S. Crolius. On the Ground in Japan: Residential Fuel Cells, Ammonia Energy May 2017, http://www.ammoniaenergy.org/on-the-ground-in-japan-residential-fuel-cells/

[30] Veissmann, Vitovalor-300P, https://professionals.viessmann.co.uk/en/residentialbuildings/combined-heat-and-power-generation/micro-chp-unit-based-on-a-fuelcell/vitovalor-300p.html

[31] M. Gandiglio, A. Lanzini, M. Santarelli, P. Leone. Design and optimization of a proton exchange membrane fuel cell CHP system for residential use, Energy and Buildings 69 (2014) 381-393 
[32] Ofgem, Decision on revised Typical Domestic Consumption Values for gas and electricity (2017)

https://www.ofgem.gov.uk/system/files/docs/2017/08/tdcvs_2017_decision.pdf

[33] Department of Transport, National Travel Survey England 2014 (2015).

https://assets.publishing.service.gov.uk/government/uploads/system/uploads/attachment_data /file/457752/nts2014-01.pdf

[34] Ofgem, Feed In Tariff rates to March 2019. https://www.ofgem.gov.uk/environmentalprogrammes/fit/fit-tariff-rates

[35] I. Staffell, R Green. The cost of domestic fuel cell micro-CHP systems, International Journal of Hydrogen Energy 38 (2013) 1088-1102

[36] Department for Business, Energy \& Industrial Strategy. The future for small-scale lowcarbon generation(2019). https://www.gov.uk/government/consultations/the-future-for-smallscale-low-carbon-generation

[37] Energy Saving Trust. Measurement of Domestic Hot Water Consumption in Dwellings (2008), https://www.gov.uk/government/publications/measurement-of-domestic-hot-waterconsumption-in-dwellings

[38] A J Summerfield, T Oreszczyn, I G Hamilton, D Shipworth, G M Huebner, R J Lowe, P Ruyssevelt. Empirical variation in 24-h profiles of delivered power for a sample of UK dwellings: Implications for evaluating energy savings. Energy and Buildings 88 (2015) 193202

[39] M Eames, T Kershaw, D Coley. On the creation of future probabilistic design weather years from UKCP09, Building Serv. Eng. Res. Technol. 32,2 (2011) pp. 127-142

[40] Met Office. UK Climate Projections UKCP09 (2018).

http://ukclimateprojections.metoffice.gov.uk/

[41] G. J. Levermore, J. B. Parkinson. Analyses and algorithms for new test reference years and design summer years for the UK. Building Serv. Eng Res Tech (2006); 27: 311-25. 
[42] H.R. Ellamla, I Staffell, P. Bujlo, B. G. Pollet, S Pasupathi. Current status of fuel cell based combined heat and power systems for residential sector. Journal of Power Sources (2015) 293 pp 312-328.

[43] R. Lowe, A. Summerfield, E. Oikonomou, J. Love, P. Biddulph, C. Gleeson, L. Chiu, J. Wingfield. Final report on analysis of heat pump data from the Renewable Heat Premium Payment (RHPP) Scheme (2017). Rapid HPC for BEIS, https://assets.publishing.service.gov.uk/government/uploads/system/uploads/attachment_data /file/606818/DECC_RHPP_161214_Final_Report_v1-13.pdf

[44] Department for Business, Energy \& Industrial Strategy. DUKES Chapter 5 (Electricity) (2018) https://www.gov.uk/government/statistics/electricity-chapter-5-digest-of-unitedkingdom-energy-statistics-dukes

[45] P.E. Dodds, I. Staffell, A.D. Hawkes, F. Li, P. Grunewald, W. McDowall, P. Ekins. Hydrogen and fuel cell technologies for heating: A review. International Journal of Hydrogen Energy (2015) 40,5 pp 2065-2083.

[46] J. Batterbee. Domestic Energy Services. Energy Technologies Institute (2018) https://www.eti.co.uk/insights/domestic-energy-services

[47] H.J. Hannon, T.J. Foxon, W.F.Gale. The co-evolutionary relationship between Energy Service Companies and the UK energy system: Implications for a low-carbon transition. Energy Policy (2013) 61 pp 1031-1045. 